\title{
Characteristic Studies on Whisker-Reinforced Borosilicate Glasses
}

\author{
A. Behairy \\ The High Institute of Engineering and Technology in New Damietta, Damiette, Egypt \\ Email: amalbehairy00@gmail.com
}

How to cite this paper: Behairy, A. (2019) Characteristic Studies on Whisker-Reinforced Borosilicate Glasses. New Journal of Glass and Ceramics, 9, 15-24.

https://doi.org/10.4236/njgc.2019.92002

Received: January 12, 2019

Accepted: March 10, 2019

Published: March 13, 2019

Copyright (C) 2019 by author(s) and Scientific Research Publishing Inc. This work is licensed under the Creative Commons Attribution International License (CC BY 4.0).

http://creativecommons.org/licenses/by/4.0/

\begin{abstract}
Glass composition of fixed values of the structural factor $\mathrm{R}\left(\mathrm{CdO} / \mathrm{B}_{2} \mathrm{O}_{3}\right)=0.5$ and $\mathrm{K}\left(\mathrm{SiO}_{2} \mid \mathrm{B}_{2} \mathrm{O}_{3}\right)=0.5$ in borosilicate glass modified by $\mathrm{CdO}$ has been studied by different techniques. The amorphous structure of as prepared glass was confirmed by both XRD and EDP spectroscopy. The amorphous samples were treated thermally to be transformed to suitable type of crystalline glass ceramic. Based on SEM and TEM data, the bulk crystallized network was developed by treating the glasses at high treatment route $\left(950^{\circ} \mathrm{C}-1100^{\circ} \mathrm{C}\right)$ for a specific time (8 hours). Crystalline $\mathrm{Al}_{4} \mathrm{~B}_{2} \mathrm{O}_{9}$ and $\mathrm{Al}_{18} \mathrm{~B}_{4} \mathrm{O}_{33}$ whisker phases are simply detected by X-ray diffraction spectroscopy. The scanning and transmission electron microscopes (SEM and TEM) have confirmed that aluminum borate crystalline phases in the form of whiskers (rods) species are the main formed type. Both size and concentration of the whisker species were increased with increasing temperature of thermal heat treatment. Formation of this type of crystals (whiskers) leads to interlocking microstructure and as a direct result, an increase in hardness number, glass transition temperature is simply evidenced. Glass-ceramics synthesized in this study can be applied as high temperature resistant materials because their microstructures can resist micro-cracking upon indentation. The crack length due to indentation process is reduced by increasing concentration of crystalline road or whisker like structure.
\end{abstract}

\section{Keywords}

Glasses and Glass Ceramics, Whisker Phases, Crystalline Structure-X-Diffraction

\section{Introduction}

Ceramic or glass ceramics in the systems $\mathrm{SiO}_{2}-\mathrm{Al}_{2} \mathrm{O}_{3}, \mathrm{Al}_{2} \mathrm{O}_{3}-\mathrm{B}_{2} \mathrm{O}_{3}$ and $\mathrm{Al}_{2} \mathrm{O}_{3}-\mathrm{B}_{2} \mathrm{O}_{3}-\mathrm{SiO}_{2}$ [1] [2] [3] [4] [5] have been considered as important and versatile compounds. 
Their properties include high thermal stability, very low thermal expansion, low heat conductivity, high creep and corrosion resistance and high stiffness [1] [2] [3]. Special attention has been paid toward glass ceramics containing some specific types of crystals. In this regard whiskers type is useful substance applied to resist deformation and crack propagation in materials [2] [3] [4] [5]. Whisker is generally referred to a certain phase with high aspect ratio (i.e. length/diameter). Presence of crystals of road like shapes in the glass ceramic matrix reinforces its network structure [5] [6] [7]. The direct growth of dispersed whiskers in a glass matrix to form a glass-ceramic leads to improvements of material properties especially mechanical properties. This includes increased fracture toughness, hardness and improved thermal shock resistance [2] [4] [5]. Aluminum borate whiskers are considered to have great potentials for fabricating hard and tough topographical microstructures stable for applications.

The crystallization behavior of glasses in the $\mathrm{Al}_{2} \mathrm{O}_{3}-\mathrm{B}_{2} \mathrm{O}_{3}-\mathrm{SiO}_{2}$ system has recently been investigated [4] [5]. It was showing that whisker of aluminum borate phase was crystallized out above glass transition temperature of the as-prepared glass. Several studies have reported that the bulk crystallization of borosilicate glasses can be affected by different factors, for example change of the glass composition, thermal heat treatment and irradiation processes. All have a great effect on bulky crystallization of the glass or glass ceramics [2] [3] [4] [8] [9] [10]. Crystalline $\mathrm{Al}_{4} \mathrm{~B}_{2} \mathrm{O}_{9}$ and $\mathrm{Al}_{18} \mathrm{~B}_{4} \mathrm{O}_{33}$ phases are simply formed in aluminum borosilicate glasses by effect of heat treatment [2] [4] [11].

The size of aluminum borate whiskers/rods increases with increasing time of thermal treating. Usually the whisker/rod-like crystals are uniformly oriented throughout the microstructure in the heat treated samples [2] [8] [9] [10] [11]. This led to a structure characterized with several types of sub crystals which are joint together firmly and hence an increase in hardness and fracture toughness is observed. As a result, the microstructure of such materials can resist micro-cracking and scratching upon indentation.

This work is aimed to determine the phase evolution, microstructures, micro hardness and crack propagation in the investigated glass and glass ceramics. The additional aim of this study is to shed more light on the effect of thermal heat treatments process on mechanism of formation of $\left(\mathrm{Al}_{18} \mathrm{~B}_{4} \mathrm{O}_{33}\right)$ and $\left.\mathrm{Al}_{4} \mathrm{~B}_{2} \mathrm{O}_{9}\right)$ whisker phases which have refractory properties and corrosion resistance [1] [12] [13].

\section{Experimental}

\subsection{Samples Preparation}

Glass of composition $\mathrm{B}_{2} \mathrm{O}_{3}-\mathrm{SiO}_{2}-\mathrm{Al}_{2} \mathrm{O}_{3}-\mathrm{CdO}$ was prepared using a melt-annealed route. Mixtures of analytical grade $\mathrm{SiO}_{2}$ (Prince Minerals Ltd., UK), $\mathrm{H}_{3} \mathrm{BO}_{3}$, $\mathrm{Al}_{2} \mathrm{O}_{3}$ and $\mathrm{CdO}$ (all Sigma-Aldrich) were melted in an aluminum crucible for $1 \mathrm{~h}$ at $1420^{\circ} \mathrm{C}$ in an electric furnace. After melting, the liquid was rapidly poured between stainless steel plates and directly annealed at $400^{\circ} \mathrm{C}$ to enhance the 
crystallization process. The as obtained samples were obtained in an amorphous state as confirmed by powder X-ray diffraction experiments. Heat treatment was applied on the as-obtained glass using a heating and cooling rate of $5^{\circ} \mathrm{C} / \mathrm{min}$. The temperature was hold at fixed values $\left(950^{\circ} \mathrm{C}, 1000^{\circ} \mathrm{C}\right.$ and $\left.1100^{\circ} \mathrm{C}\right)$ for a fixed time for 8 hours.

\subsection{Measurements}

XRD diffraction patterns were carried out on aBrucker Axs-D8 spectrometer. Emitting source of type $(\lambda \mathrm{CuK} \alpha)$ has been utilized. The numerical data was steeply accumulated with a small scanning step, $2 \theta$ rang of $5^{\circ}-70^{\circ}$ and a dwell time of 0.4 seconds have been applied. The obtained X-ray diffraction spectra were revised to reference samples related to standards which were gathered by the technique of powder diffraction and standards (JCDPS).

Transmission Electron Microscopy (TEM) is a common technique used to assess the shape, size, and morphology of the bulk of the material. TEM were performed on a JEOL-JEM-2100 (Mansoura University), with an electron acceleration voltage of $200 \mathrm{kV}$. During this technique, a high energy beam of electrons is transmitted through a very thin specimen, causing interactions between the electrons and the atoms and producing the TEM images. The surface structure of samples was characterized using JEOL JSM-6510 LV electron microscope operated at accelerating voltage $30 \mathrm{KV}$, with a magnification $10 \times$ up to $400.000 \times$. For the SEM study, the samples were coated with gold to prevent scattering of the electron beam. Hardness was obtained from a HV-1000B Vickers microhardness tester with a load of $300 \mathrm{~g}$ on a mirror finish surface.

\section{Results}

Figure 1 shows DSC curve for the as prepared sample. The crystalline temperature is evaluated to be around $940^{\circ} \mathrm{C}$. Exothermic peaks corresponding to crystallization process are dependent on the route of thermal heat treatment. Figure 2 represents XRD spectra of both as prepared and thermally treated glasses. The network structure of the as prepared glass was confirmed to be amorphous. This is can be evidenced by appearing of a broad X-ray diffraction pattern characterizing the amorphous state of the glass as is shown in Figure 2(a). The amorphous nature of as prepared sample is further confirmed by electron diffraction patterns (EDP), Figure $4(\mathrm{c})$, since there is no any diffraction due to crystalline species could be observed. Treating the glass thermally leads to formation of some types of crystalline species as is evidenced from Figures 2(b)-(d) and Figure 4(d). In this regard, some sharp diffractions are simply appeared. This leads that the applied temperature plays the role of transformation of amorphous phase into more ordered crystalline ones.

The present glass is treated thermally at higher temperature than that of crystalline one. Thermal heat treatment temperature is therefore $\geq 950^{\circ} \mathrm{C}$ which may the proper temperatures valuable for transformation of the amorphous structure 
into crystalline one as is evidenced from DSC curve (Figure 1) and both XRD and EDP (Figures 2(b)-(d) and Figure 4(d)). The will formed crystalline phases are indexed to some specific type of whisker phase [1] [2] [3] [8] [10] which are distributed in the residual glass matrix.

The morphology of as prepared sample was studied by Scanning Electron Microscopy (SEM) and TEM (Figure 3 and Figure 4). The photograph of base glass is shown by Figure 3(a) which shows a homogenous morphology of the glass network. Noteworthy, heating the base glass at a specific temperature for fixed time of treating successfully led to the formation of crystalline nano-fibrous or whiskers bundles (Figure 3(b) and Figure 3(c)). Treatments at the higher temperature for the same time can simply form co-aligned and elongated nanodifused species (Figure $3(\mathrm{~d})$ ). The formed nano rods may contain $\mathrm{Al}_{4} \mathrm{~B}_{2} \mathrm{O}_{9}$ and $\mathrm{All}_{8} \mathrm{~B}_{4} \mathrm{O}_{33}$ nano-crystals which are considered to be useful for using the materials in the field of tissue engineering and bio scaffolds applications.

Table 1 presents the relation between the micro hardness number and tempering temperature of heat treatment. There is a significant change in the hardness number with the effect of increasing temperature of treatment. $\mathrm{H}_{\mathrm{v}}$ is increased gradually and the values were $350 \mathrm{Kg} / \mathrm{mm}^{2}$ for as prepared glass, 396 $\mathrm{Kg} / \mathrm{mm}^{2}$ for glass treating at $1000^{\circ} \mathrm{C}$ and $485 \mathrm{Kg} / \mathrm{mm}^{2}$ for sample heat treated at $1100^{\circ} \mathrm{C}$, respectively. The as obtained glass has a lower number of hardness. In addition, the crack length and distortion due to indentation process at the corner of diamond pyramid was also observed to be lowered by increasing treating temperature (Table 1). This may lead that the microstructure of high hardness number and lower crack length can resist crack propagation in solid materials.

\section{Discussion}

\subsection{XRD Analysis}

Several studies on oxide glasses and glass ceramics had indicated that the structure of glass network depends strongly on, morphology and crystallinity relationships [1] [14] [15] [16]. To control formation of some specific types of crystalline species, employment of sensitive and specific technique has to be required. The applied method of thermal heat treatment (THT) is considered between the most suitable routes. The THT may be applied to obtain morphology with certain desired crystalline phases characterized glass ceramics. Figure 2 presents XRD patterns of crystallized glass samples treated at different temperature $\left(950^{\circ} \mathrm{C}, 1000^{\circ} \mathrm{C}\right.$ and $\left.1100^{\circ} \mathrm{C}\right)$ for fixed time interval $(8 \mathrm{hrs})$. Peaks at $2 \theta=$ $16.5^{\circ} \mathrm{C}$ and $21^{\circ} \mathrm{C}$ appeared in XRD curve are assigned to the semi-crystalline $\mathrm{Al}_{4} \mathrm{~B}_{2} \mathrm{O}_{9}$. At the same time, some new peaks were appeared at $1000^{\circ} \mathrm{C}$ and $1100^{\circ} \mathrm{C}$. Then $\mathrm{XRD}$ curves at $1000^{\circ} \mathrm{C}$ and $1100^{\circ} \mathrm{C}$ showed predominating crystalline species of $\mathrm{Al}_{4} \mathrm{~B}_{2} \mathrm{O}_{9}$ in addition to growth of some traces of $\mathrm{Al}_{18} \mathrm{~B}_{4} \mathrm{O}_{33}$ [16] [17]. However the intensity of peaks increased with increasing treating temperature from $950^{\circ} \mathrm{C}$ to $1100^{\circ} \mathrm{C}$. Formation of whisker crystals at temperature $950^{\circ} \mathrm{C}$ and $1000^{\circ} \mathrm{C}$ can be correlated with $\mathrm{Al}_{4} \mathrm{~B}_{2} \mathrm{O}_{9}$ phase according to XRD data 
as shown in Figure 2(b) and Figure 2(c). Increasing crystallization temperature led to an enhanced growth of the crystals, since both $\mathrm{Al}_{4} \mathrm{~B}_{2} \mathrm{O}_{9}$ and $\mathrm{Al}_{18} \mathrm{~B}_{4} \mathrm{O}_{33}$ [11] [16] [17] could be identified by XRD patterns of glass treated at $1100^{\circ} \mathrm{C}$ (Figure 2(d)). Presence of the same crystalline species is also documented in aluminum borate glasses treated at lower temperature [11]. The formation of aluminum borates $\left(\mathrm{Al}_{18} \mathrm{~B}_{4} \mathrm{O}_{33}\right.$ and $\left.\mathrm{Al}_{4} \mathrm{~B}_{2} \mathrm{O}_{9}\right)$ from alumina and boron oxide occurs between $600^{\circ} \mathrm{C}$ and $800^{\circ} \mathrm{C}$ in aluminum borate glasses [11]. But in the present investigated aluminum borosilicate glasses these phases are obtained at more higher temperature $1000^{\circ} \mathrm{C}$ and $1100^{\circ} \mathrm{C}$. Thermal treating technique is the most recommended to obtain morphologies with a better crystallinity as is evidenced from Figure 2(d) and Figure 3(b). These characteristics become essential to improve the structure of the used materials.

\subsection{Morphological Studies (SEM and TEM) Microscopy}

The morphology and bulk structure of as prepared glass were characterized by

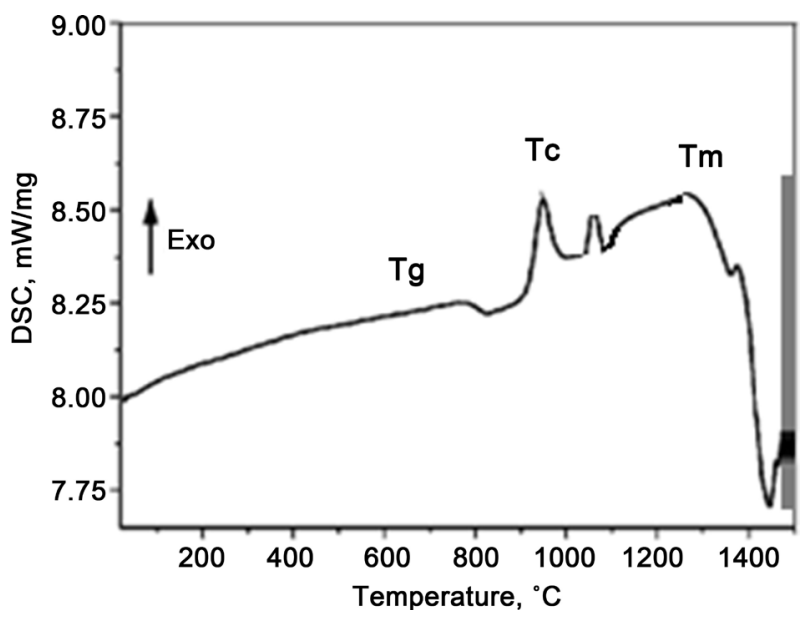

Figure 1. DSC curve for as prepared sample.

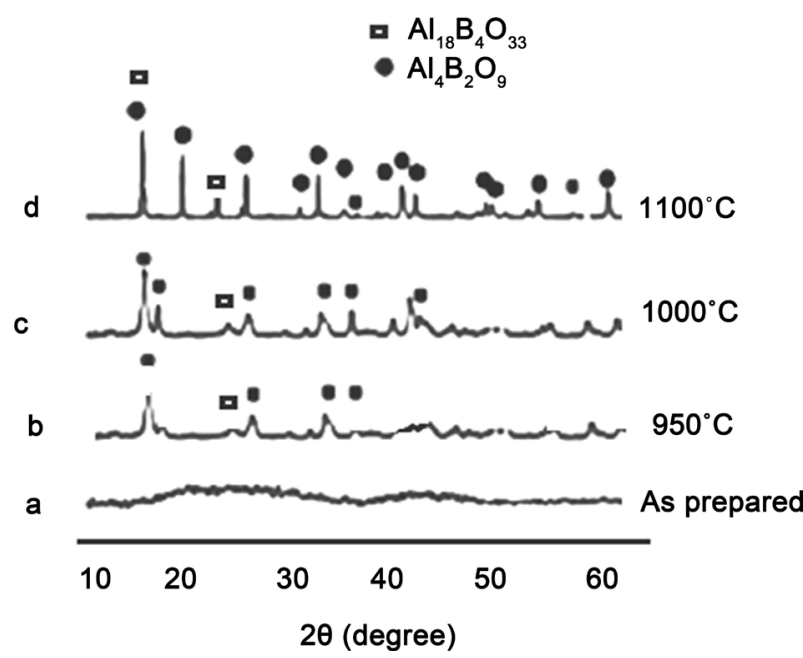

Figure 2. XRD patterns (a) for as prepared glass-ceramic, (b) $950{ }^{\circ} \mathrm{C}$, (c) $1000^{\circ} \mathrm{C}$, and (d) $1100^{\circ} \mathrm{C}$. 
scanning and transmission electron microscopy (SEM and TEM). The micrograph of base glass is presented by Figure 3(a) and Figure 4(a) which show nearly homogenous glass network. Noteworthy, treating of the amorphous borosilicate glass at a specific temperature for fixed time of treating successfully led to the formation of crystalline alumina-borate nano-fibrous or whiskers bundles (Figure 3(b) and Figure 4(b)). Treatments at higher temperature for the same time can simply form co-aligned and elongated nanodifused species (Figure $3(c))$ which is transformed to more aligned thicker elongated and diffused nono-fibers or whiskers (Figure $3(\mathrm{~d})$ ). The well formed fibers are characterized with $15-20 \mathrm{~nm}$ thick and up to ca. $40 \mu \mathrm{m}$ long. The formed nanofibers consisted of $\mathrm{Al}_{4} \mathrm{~B}_{2} \mathrm{O}_{9}$ and $\mathrm{Al}_{18} \mathrm{~B}_{4} \mathrm{O}_{33}$ nano-crystals, with the better-elongated shapes which are considered to be useful for using the materials in the field of tissue engineering or bio scaffolds applications.

As important advantage, this treated glass ceramics can be performed under relatively mild conditions (applied THT at $1000^{\circ} \mathrm{C}$ and $1100^{\circ} \mathrm{C}$ for $8 \mathrm{hrs}$ ). Such conditions, are often necessary to obtain high aspect ratio of elongated $\mathrm{Al}_{4} \mathrm{~B}_{2} \mathrm{O}_{9}$ and $\mathrm{Al}_{18} \mathrm{~B}_{4} \mathrm{O}_{33}$ nanofibers [18] [19] [20], and they have been also successfully employed as templates in the transcription of nanofibrous inorganic materials and hybrid biomaterials [21]. SEM showed that the size of the well-formed crystalline species is varied with increasing heat treatment temperature. Smaller
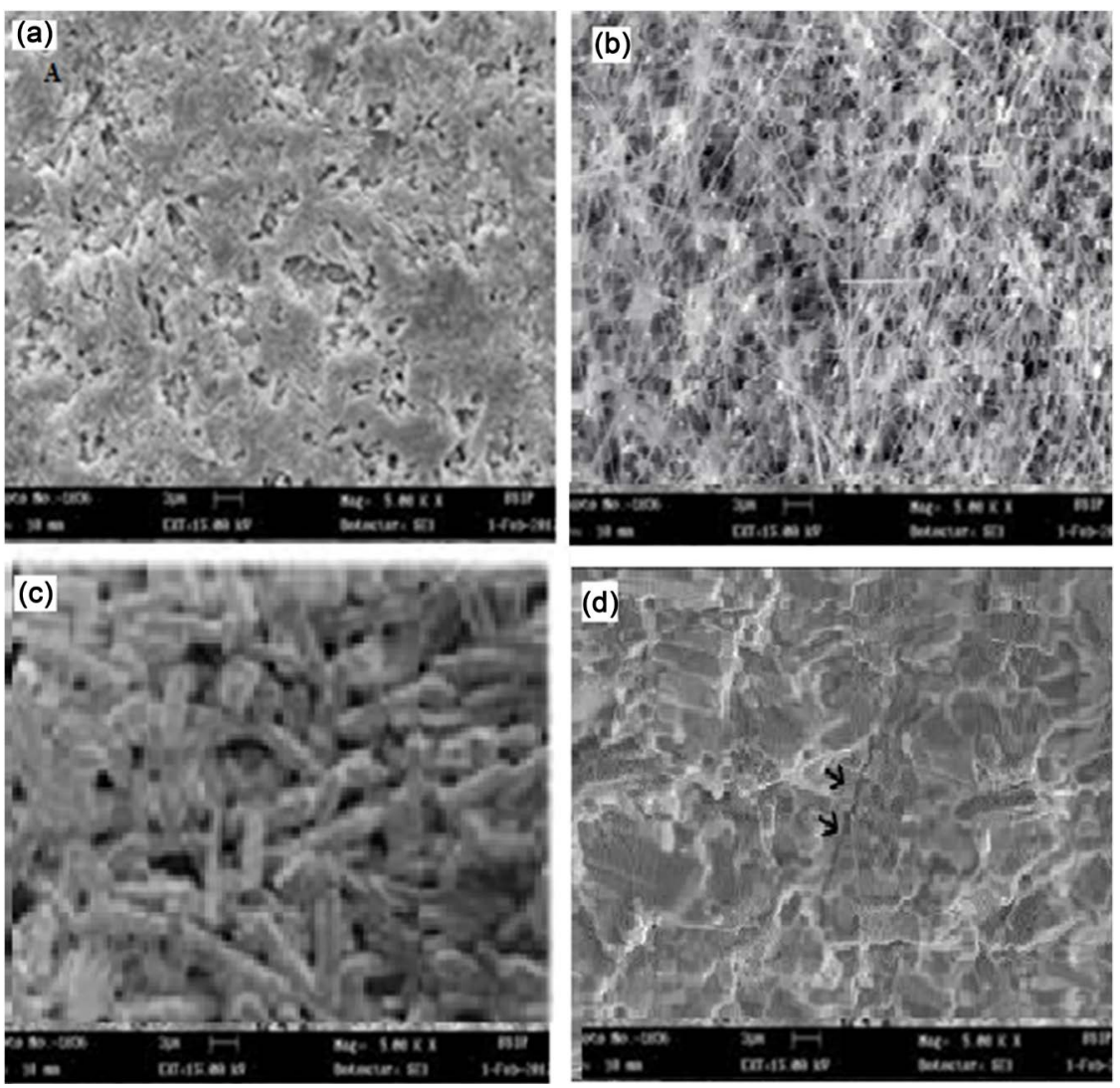

Figure 3. SEM ofasa prepared glass-ceramic (a) and for heattreated glasses at different temperatures for 8 hours: (b) $950{ }^{\circ} \mathrm{C}$, (c) $1000{ }^{\circ} \mathrm{C}$, (d) $1100{ }^{\circ} \mathrm{C}$. 


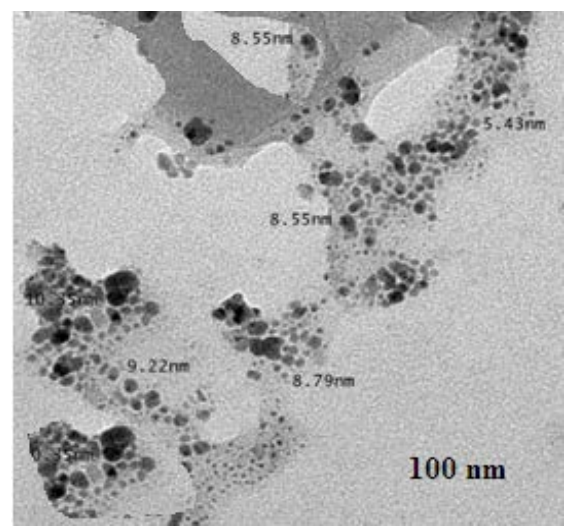

(a)

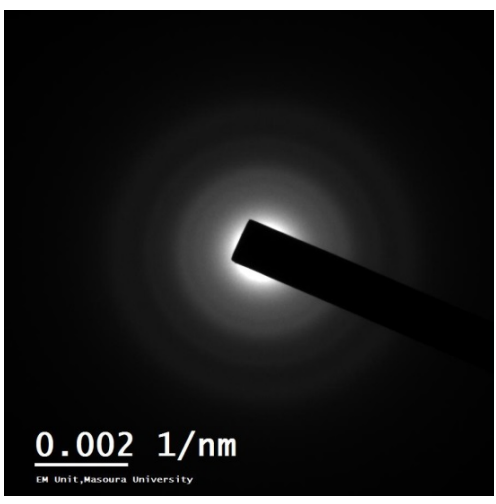

(c)

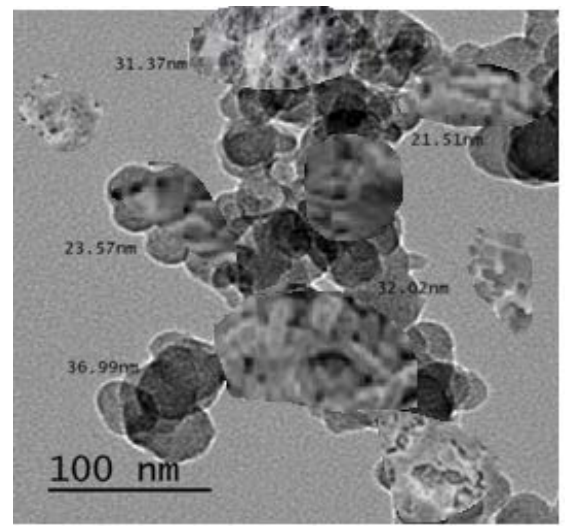

(b)

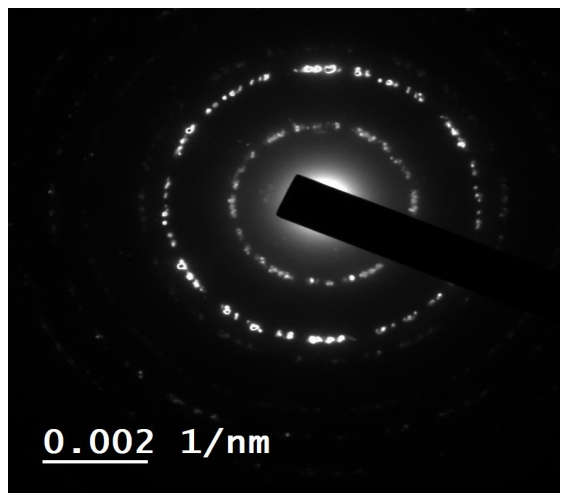

(d)

Figure 4. TEM of as prepared glass-ceramic (a) and for heat treated glasses at treated at $1100^{\circ} \mathrm{C}(\mathrm{b}) . \mathrm{EDP}$ of as prepared glass (c) and of glass treated at $1100^{\circ} \mathrm{C}(\mathrm{d})$.

crystals were found in samples heat treated at lower temperature. It is also reflected from the electron diffraction pattern (EDP) that the structure of the sample treated at $1000^{\circ} \mathrm{C}$ is more oriented and ordered than that of as obtained glass, see Figure 4(c) and Figure 4(d). Finally, heat treatment at extra higher temperature $1100^{\circ} \mathrm{C}$ resulted in partially melting of some hollow aluminumborate rods and a change in crystal morphology, see Figure $3(d)$. Therefore, $1000^{\circ} \mathrm{C}$ is considered the suitable temperature for heat treatment process.

\subsection{Microhardness Investigation}

Table 1 presents the relation between the micro hardness number and tempering temperature of heat treatment. There is a significant change in the hardness number with the effect of increasing temperature of treatment. Hv is increased gradually and the values were 350 for as prepared glass, 396 for glass treating at $1000^{\circ} \mathrm{C}$ and $485 \mathrm{Kg} / \mathrm{mm}^{2}$ for sample heat treated at $1100^{\circ} \mathrm{C}$, respectively. The as obtained glass has lower number of hardness. In addition, the crack length and distortion due to indentation process at the corner of diamond pyramid was also observed to be lowered by increasing treating temperature. This may lead that the microstructure of high hardness number and lower crack length can resist crack propagation in solid materials [22] [23]. 
Table 1. Change of hardness number and crack length with temperature.

\begin{tabular}{ccccc}
\hline Treating temperature & As prepared & $1000^{\circ} \mathrm{C}$ & $1100^{\circ} \mathrm{C}$ & $1150^{\circ} \mathrm{C}$ \\
\hline $\mathrm{Hv}\left(\mathrm{Kg} / \mathrm{mm}^{2}\right)$ & 350 & 396 & 484 & 479 \\
Crack length $(\mu \mathrm{m})$ & 55 & 34 & 11 & 14 \\
\hline
\end{tabular}

\section{Conclusion}

The formation of aluminum borates $\left(\mathrm{Al}_{18} \mathrm{~B}_{4} \mathrm{O}_{33}\right.$ and $\left.\mathrm{Al}_{4} \mathrm{~B}_{2} \mathrm{O}_{9}\right)$ crystalline phases in borosilicate glass ceramics occur between $1000^{\circ} \mathrm{C}$ and $1100^{\circ} \mathrm{C}$. There is a development in microstructure and properties upon thermal heat treatment. The differential thermal analysis was carried out to evaluate the limit of the sintering process. Then the degree of crystal formation was confirmed by X-ray and electron diffraction. Finally, the developed microstructures were characterized by scanning and transmission electron microscopy. The obtained results have confirmed that $\mathrm{Al}_{18} \mathrm{~B}_{4} \mathrm{O}_{33}$ is the main crystalline phase. Needle grains like shape were dominant crystal type. The various heat treatment temperatures mainly influenced the content of $\left(\mathrm{All}_{8} \mathrm{~B}_{4} \mathrm{O}_{33}\right.$ and $\left.\mathrm{Al}_{4} \mathrm{~B}_{2} \mathrm{O}_{9}\right)$ crystalline species in the glass-ceramic. Glass-ceramic treated at $1100^{\circ} \mathrm{C}$ presented the highest crystallinity and hardness number and lowest crack length. SEM and TEM showed that a large number of whisker crystalline phases together with the glassy phases were evenly distributed in the network of glass ceramic treated at $1000^{\circ} \mathrm{C}$ and $1100^{\circ} \mathrm{C}$. The results indicated that thermal heat treatment process creates more crystalline species of more chemical bonds which acted as a vital part in improving the holding power for the bonding of glass-ceramic bonds and increasing the glass hardness and reducing the crack concentrations.

\section{Conflicts of Interest}

The author declares no conflicts of interest regarding the publication of this paper.

\section{References}

[1] Schneider, H. and Komarneni S. (2005) Mullite. Wiley-VCH, Weinheim. https://doi.org/10.1002/3527607358

[2] Sooksaen, P., Prasertcharoensuk, P., Damnernsawat, P. and Pattamawitayanimit, N. (2013) High Indentation Resistance of Aluminum Borate Based Glass-Ceramics. Key Engineering Materials, 545, 3 -7. https://doi.org/10.4028/www.scientific.net/KEM.545.3

[3] Li, J.X., Narita, T., Ogawa, J. and Wadasako, M. (1998) In Situ Synthesis of Porous Ceramics with a Framework Structure of Aluminium Borate Whisker. Journal of Materials Science, 33, 2601-2605. https://doi.org/10.1023/A:1004309403901

[4] Cheng, Y., Xiao, H.N., Chen, S.G. and Tang B.Z. (2009) Structure and Crystallization of $\mathrm{B}_{2} \mathrm{O}_{3}-\mathrm{Al}_{2} \mathrm{O}_{3}-\mathrm{SiO}_{2}$ Glasses. Physica B: Condensed Matter, 404, 1230-1234. https://doi.org/10.1016/j.physb.2008.11.198

[5] Lee, H.K., Zerbetto, S., Colombo, P. and Pantano, C.G. (2010) Glass-Ceramics and Composites Containing Aluminum Borate Whiskers. Ceramics International, 36, 
1589-1596. https://doi.org/10.1016/j.ceramint.2010.02.039

[6] Becher, P.F., Hsueh, C.H., Angelini, P. and Tiegs, T.N. (1988) Toughening Behavior in Whisker-Reinforced Ceramic Matrix Composites. Journal of the American Ceramic Society, 71 1050-1061. https://doi.org/10.1111/j.1151-2916.1988.tb05791.x

[7] Okada, K. and Otuska N. (1991) A Novel Method for Molding Ceramic-Powder Based on a Synthesis of Concepts Derived from Traditional Ceramics. Journal of the American Ceramic Society, 74, 2412-2418.

[8] El-Damrawi, G., Hassan, A.K. and El-Jadal, S. (2017) Morphological and Structural Investigations on Iron Borosilicate Glasses. New Journal of Glass and Ceramics, 7, 13-21. https://doi.org/10.4236/njgc.2017.72002

[9] El-Damrawi, G., Müller-Warmuth, W., Doweidar, H. and Gohar, I.A. (1992) Structure and Heat Treatment Effects of Sodium Borosilicate Glasses as Studied by ${ }^{29} \mathrm{Si}$ and ${ }^{11}$ B NMR. Journal of Non-Crystalline Solids, 146, $137-144$. https://doi.org/10.1016/S0022-3093(05)80485-5

[10] Schuller, S., Pinet, O., Grandjean, A. and Blisson, T. (2008) Phase Separation and Crystallization of Borosilicate Glass Enriched in $\mathrm{MoO}_{3}, \mathrm{P}_{2} \mathrm{O}_{5}, \mathrm{ZrO}_{2}, \mathrm{CaO}$. Journal of Non-Crystalline Solids, 354, 296-300. https://doi.org/10.1016/j.jnoncrysol.2007.07.041

[11] Sooksaen, P. (2012) Structure and Crystallization of Borate-Based Glasses for Machinable Material Applications. International Journal of Applied Physics and Mathematics, 2, 43.

[12] Hernández, M.F., Suarez, G., Cipollone, M. and Rendtorff, N.M. (2016) Formation, Microstructure and Properties of Aluminum Borate Ceramics Obtained from Alumina and Boric Acid. Ceramic International, 43, 2188-2195. https://doi.org/10.1016/j.ceramint.2016.11.002

[13] Fisch, M., Armbruster, T., Rentsch, D., Libowitzky, E. and Pettke, T. (2010) Crystal-Chemistry of Mullite-Type Aluminoborates $\mathrm{Al}_{18} \mathrm{~B}_{4} \mathrm{O}_{33}$ and $\mathrm{Al}_{5} \mathrm{BO}_{9}$ : A Stoichiometry Puzzle. Journal of Solid State Chemistry, 148, 70-80. https://doi.org/10.1016/j.jssc.2010.10.032

[14] Werding, G. and Schreyer, W. (1984) Alkali-Free Tourmaline in the System $\mathrm{MgO}-\mathrm{Al}_{2} \mathrm{O}_{3}-\mathrm{B}_{2} \mathrm{O}_{3}-\mathrm{SiO}_{2}-\mathrm{H}_{2} \mathrm{O}$. Geochimica et Cosmochimica Acta, 48, 1331-1344. https://doi.org/10.1016/0016-7037(84)90066-8

[15] Werding, G. and Schreyer, W. (1996) Reviews in Mineralogy. Mineralogical Society of America, Washington DC, 117-163.

[16] Mazza, D., Vallina, M. and Busca, G. (1992) Transformation Plasticity and Toughening in $\mathrm{CeO}_{2}$-Partially-Stabilized Zirconia-Alumina (Ce-TZP/ $/ \mathrm{Al}_{2} \mathrm{O}_{3}$ ) Composites Doped with MnO. Journal of the American Ceramic Society, 75, 1229-1238. https://doi.org/10.1111/j.1151-2916.1992.tb05562.x

[17] Chung, T.T., Lee, C.C. and Fan, K.C. (2005) Optimum Design of a $1 \times 2$ Mechanical Optical Switch. Structural and Multidisciplinary Optimization, 31 229-240. https://doi.org/10.1007/s00158-005-0580-7

[18] Chun, C., Ding, X.X., Shi, F.J., Yun, C., Huang, X.T., Qi, S.R. and Tang, C. (2004) Preparation of Aluminum Borate Nanowires. Journal of Crystal Growth, 263, 600-604. https://doi.org/10.1016/j.jcrysgro.2003.11.052

[19] Peng, L.M., Li, X.K., Li, H., Wang, J.H. and Gong, M. (2006) Synthesis and Microstructural Characterization of Aluminum Borate Whiskers. Ceramics International, 32, 365-368. https://doi.org/10.1016/j.ceramint.2005.03.013

[20] Li, Y. and Chang, R.P.H. (2006) Synthesis and Characterization of Aluminum Bo- 
rate $\left(\mathrm{Al}_{18} \mathrm{~B}_{4} \mathrm{O}_{33}, \mathrm{Al}_{4} \mathrm{~B}_{2} \mathrm{O}_{9}\right)$ Nanowires and Nanotubes. Materials Chemistry and Physics, 97, 23-30.

[21] Llusar, M. and Sanchez, C. (2008) Inorganic and Hybrid Nanofibrous Materials Templated with Organogelators. Chemistry of Materials, 20, 782-820. https://doi.org/10.1021/cm702141e

[22] Song, X., Liu, W., Wang, J., Xu, S., Liu, B., Liu, J. and Ceramics, Y.M. (2017) Microstructural Differences between Electrospun Alumina Borate Nanofibers Prepared by Solutions with Different PVP Contents. Ceramics International, 43, 9831-9837. https://doi.org/10.1016/j.ceramint.2017.04.163

[23] Wang, Y., Sunarso, J., Wang, F., Zhao, B., Liu, X., et al. (2017) Electrospinning and Hydrothermal Synthesis of Recyclable $\mathrm{MoS}_{2} / \mathrm{CNF}$ sybrid with Enhanced Visible-Light Photocatalytic Performance. Ceramics International, 43, 11028-11033. https://doi.org/10.1016/j.ceramint.2017.05.145 